\title{
Parental Beliefs on Child Development of Children with Developmental Delays
}

\author{
Wesley Correa ${ }^{1}$ (D) https://orcid.org/0000-0001-7597-6428 \\ Maria de Fátima Minetto ${ }^{1}$ (D) https://orcid.org/0000-0002-6796-1610 \\ Rafaeli Cappellaro-Kobren ${ }^{1}$ (D) https://orcid.org/0000-0002-8087-1759 \\ Leandro Kruszielski1 (D) https://orcid.org/0000-0002-8938-9272
}

\begin{abstract}
Parental beliefs on child education and development might intervene in how parents relate to their children and promote their development. The present research aimed to identify parental beliefs about the development of children with developmental delays. For this, we took a qualitative approach, based on content analysis, from the answers obtained in the Questionnaire of Parental Beliefs on Child Development. We obtained answers of 36 families (fathers and mothers) of 40 children with different developmental delays, attending the Municipal Child Education Centers of a capital of the South region of Brazil. We could identify beliefs regarding the development of children, which were mainly understood as aspects related to the delays the child presented (negative) and to their achievements (positive), which represented the way in which these parents direct their parental educational practices.
\end{abstract}

Keywords: child development, family relationships, developmental disabilities

\section{Crenças Parentais sobre Desenvolvimento Infantil de Crianças com Atrasos no Desenvolvimento}

\begin{abstract}
Resumo: As crenças parentais em relação à educação e ao desenvolvimento da criança estão sujeitas a intervir no modo como os pais relacionam-se com seus filhos e promovem seu desenvolvimento. A presente pesquisa teve como objetivo identificar as crenças parentais sobre o desenvolvimento infantil de crianças com atrasos no desenvolvimento. Para tanto, a pesquisa assumiu método qualitativo, com base em análise de conteúdo, a partir das respostas obtidas do Questionário de Crenças Parentais sobre o Desenvolvimento Infantil. Este instrumento foi respondido por 36 famílias (pais e mães) de 40 crianças, com diferentes atrasos no desenvolvimento, que frequentam os Centros Municipais de Educação Infantil de uma capital da região Sul do Brasil. Foi possível identificar crenças em relação ao desenvolvimento das crianças, sendo estas compreendidas principalmente, por aspectos ligados aos atrasos que a criança apresentava (negativas) e às suas conquistas (positivas), o que representa o modo como estes pais direcionam suas práticas educativas parentais.
\end{abstract}

Palavras-chave: desenvolvimento infantil, relações familiares, deficiências do desenvolvimento

\section{Creencias Parentales sobre el Desarrollo Infantil de Niños con Retrasos en el Desarrollo}

\begin{abstract}
Resumen: Las creencias parentales en relación con la educación y el desarrollo del niño están sujetas a intervenir en la forma en que los padres se relacionan con sus hijos y promueven su desarrollo. Esta investigación tuvo como objetivo identificar las creencias parentales sobre el desarrollo infantil de niños con retrasos en el desarrollo. Para ello, la investigación asumió el método cualitativo, con base en análisis de contenido, a partir de las respuestas obtenidas del Cuestionario de Creencias Parentales sobre el Desarrollo Infantil. Este instrumento fue respondido por 36 familias (padres y madres) de 40 niños con diferentes retrasos en el desarrollo, que frecuentan los Centros Municipales de Educación Infantil de una capital de la región Sur de Brasil. Es posible identificar creencias en relación al desarrollo de los niños, comprendidos principalmente, por aspectos relacionados con los retrasos que el niño presentaba (negativas) y sus conquistas (positivas), lo que representa el modo en que estos padres dirigen sus prácticas educativas parentales.
\end{abstract}

Palabras clave: desarrollo infantil, relaciones familiares, discapacidades del desarrollo

\footnotetext{
${ }^{1}$ Universidade Federal do Paraná, Curitiba-PR, Brazil

Support: Article written from the master's dissertation of the first author, under the supervion of the second, which was defended in 2017 at Programa de Pós-graduação em Processos Psicológicos em Contextos Educacionais da Univerisdade Federal do Paraná, without support of funding agencies.

Correspondence address: Wesley Correa. Universidade Federal do Paraná. Rua General Carneiro, Curitiba-PR, Brasil. CEP. 80.060-000. E-mail: wesleycorrea.psicologo@gmail.com
}

Family is the main mediating unit of the relationship between the child and his/her environment. Consequently, the development of important abilities in childhood is related to the first social interactions of the baby, especially with their parents, as they play the role of first caregivers (Ariès, 1973/2014; Conciani \& Rodrigues, 2014; 
LL Nunes \& Salomão, 2016). The socialization of a child is performed by parents according to the cultural rules and values present in the family group (Borges \& Salomão, 2015).

The first years of a child's life are permeated by the social interactions carried out at this stage, which constitute an essential process for his/her development. Such interactions are produced through his/her contact with multiple groups, acting as a reference for the child. Simultaneously they use their bio-psychological characteristics to compose their human development. Thus, human development can be characterized by involving interactions among cultural practices, different groups and the person in development in a reciprocal relation (Bronfenbrenner, 2005/2011; Harkness \& Super, 1994).

Culture plays an active role in influencing parental beliefs on child development, on education practices presented to their children, and intervenes in the outcomes of child socialization (Harkness \& Super, 1994). Therefore, undertading the beliefs, values, expectations and goals of parents relative to their children may provide us with information on the meanings of parental behaviors in the process of child socialization (Tamis-LeMonda et al., 2008).

Beliefs can be conceptualized as reflections, ideas and/ or thoughts that a person entertains about the world and the relationships that he/she establishes with it. Parental beliefs are organized into a nomenclature called parental ethnotheories that specify parents and guardians' beliefs related to the cultural patterns existing in the judgment, conceptions and perceptions of children, families, other groups, and the child itself (personal characteristics). Thus, parental beliefs are constantly underpinning the thoughts of parents; that is, they constitute tacit ideas basing the authentic and/or correct mode of thinking and acting (Harkness \& Super, 1996). According to authors such as (Borges \& Salomão, 2015, Bronfenbrenner, 2005/2011, Harkness \& Super, 1994, 1996; Virgilio \& Gonçalves, 2013; Yagodnik \& Marques, 2013), the family is the main mediator between the child and its immediate groups (school, church, among others). This is because this microsystem (family) represents the child's vital nucleus in its first years of life. Therefore these different experiences insert the child into wider social groups. Parental practices work according to beliefs developed through experiences they lived in different social groups (Nascimento \& Fernandes, 2017). Therefore, parental practices are defined not only by the parents' way of acting in relation to their children, but are also linked to positive interactions demanding responsiveness, involvement, affection and positive responses that may favor the child's development (Salvador \& Weber, 2008).

Regarding parental beliefs about child development, Borges and Salomão (2015) carried out a study with 30 mothers of $0-3$ year-old children and verified the presence of positive conceptions related to what these interviewees considered more important to their children's development. These were issues related to: health care (feeding, hygiene); affectivity (love, affection, attention); education (studying, development stimulation); and socialization (playing, social interaction, good social behavior). Regarding perception on child development, the authors reported that mothers mentioned physical, motor, social, lingustic emotional and cognitive aspects as positively related to their children. However there were also descriptions of negative aspects, related to an incompatibility between the chronological age and the height of the child (being smaller than expected) (Borges \& Salomão).

Pereira-Silva and Dessen (2007) identified greater concern by parents of children with Down syndrome (DS) $(n=5)$ regarding their motor development, schooling, professional life and sexuality. They provided different results from the group of parents of children with typical development $(n=5)$, who reported being satisfied with what they perceive on the current development of their children. The authors highlighted that the strong concern of parents of children with DS is directly related to the expectations for the future, for many of them believe that if the present difficulties are not overcome, their children will find even greater difficulties in adult life.

The term developmental delay is used in most situations during the first year of life of children who need a temporary diagnosis that may be extended until it is possible to arrive at an objective diagnostic classification, by means of psychometric tests (Franco \& Apolonio, 2010). The Dictionary of Developmental Disabilities Terminology (Accardo \& Whitman, 2003) characterizes developmental delay as a situation and/or condition in which the child does not develop and/or has a deficit to acquire certain competences during childhood, which are "expected", according to the pattern for his/her development.

In another study Ebert, Lorenzini and Silva (2015) investigated the perception of 10 mothers of children diagnosed with autism regarding the main changes in their development. Among the results, several behavioral changes and/or areas of child development were reported. Motivated by these perceptions mothers were impelled to seek medical attention for diagnosis and possible treatment for their children. Thus, the beliefs of mothers and fathers on their children's needs, potentials and development ultimately structure child raising and parental practices. The present research aimed to identify parental beliefs about the development of children with developmental delays.

\section{Method}

\section{Participants}

The study included thirty-six families from which were selected fathers and mothers of 40 children ( 31 boys and 9 girls), aged between 15.5 months (approximately one year and three months) and 68.4 months (approximately 5 years and 10 months), with a mean age of 48.33 months (approximately 4 years). The children, presenting different delays in their development, attended the Municipal Child Education Centers (CMEI's) and were previously indicated by the Coordination of Special Needs Assistance (CANE) of the Municipal Education Network (RME) of the city. 
Correa, W., Minetto, M. F., Cappellaro-Kobren, R., \& Kruszielski, L. (2019). Parental Beliefs about Child Development.

\section{Instruments}

Parental Beliefs Questionnaire on Child Development. The questionnaire was prepared by the researchers based on the literature review, and also by adapting questionnaires used in family research in previous studies (Weber \& Dessen, 2009). The main reason for the development and application of this instrument was the possibility of identification of parental beliefs on the development of children attending the CMEI's in this city. To meet the objective of this study the questionnaire consisted of two axes: Axis I (Socio-demographic data) - provided the identification and composition of the families that took part in the study, with a brief characterization of socio-demographic and family environment data. It also indicated the delays in the development of the child previously informed by the school. And Axis II (Parental Beliefs) is thematic and composed of five open questions (the answers were categorized later), which aimed to identify: how parents perceive the development of their child; how they perceive their contribution to their child's development; who assists in the child's raising care; what they desire for the future of their children, and what would it take for the child to attain the desired future.

\section{Procedure}

Data collection. After approval of the research project by the ethics committee, the CANE and some CMEIs indicated the families of children with developmental delay to compose the sample of this research. Then the researchers contacted the indicated faminilies by phone and invited them to participate in the research, informing the objectives and procedures they would have to go through to participate. The researcher also informed the families that the data collection should be carried out during a visit to the family environment in a single day and time, scheduled during this phone call.

The team of professionals who visited the family environment sought to start the data collection with an informal conversation to create the more welcoming and relaxed climate possible between researchers and interviewees. After that, the consent form was read and signed, the data collection instrument was presented, and researchers questioned the family interviewee (father, mother or both), taking notes of the answers.

Data analysis. The transcriptions of the interviewees' answers were based on content analysis, in which the researchers developed category systems that were submitted to two judges for evaluation of reliability using the equation of agreement between judges Each family received a code, as some had more than one child as participant, so that the first two numbers refer to the family, and the next two numbers to the child's.

\section{Ethical Considerations}

The research project was submitted to the Committee of Ethics in Research with Human Beings and approved by opinion No. 1,573,473 under CAEE 54244015.7.0000.0102 on June 3, 2016.

\section{Results}

\section{Sociodemographic Characterization of Interviewees}

There was a higher concentration of interviews answered by mothers alone $(n=26)$, followed by those performed by mother and father $(n=13)$. Only one interview was answered by the father alone. When the interviewees were asked who is responsible for the target child, a greater part answered that both mother and father were responsible $(n=32)$, and eight reported that it was only the mother.

There were an average number of 4.3 persons per family. Regarding the composition of the family group, the majority of interviewees were from nuclear families with biological parents of all children $(n=19)$, followed by families with a second marriage $(n=9)$, extended families $(n=7)$ with the presence of other relatives and/or friends in the residence, and single-parent families $(n=5)$. Most of the participant families live in urban areas $(n=23)$ and in the periphery $(n=16)$, and only one family resided in the center of this capital.

\section{Category System}

Categories were defined from the content found in the collected data, and constructed from the clusters of the context/record units (as thematic elements) that emerged in the analysis of the questionnaire used during the semi-structured interviews. For each question a category was delineated, resulting in five categories created during content analysis. Categories I (Development) and III (Support) were divided into three subcategories each. Category IV (Future) was classified in only one subcategory, and categories II (Contributions) and V (Needs) were distributed in two subcategories each, resulting in 16 different context/record units.

Category I entitled Development corresponds to beliefs about the child's development and is related to how parents understood of their child (ren)'s development. Parents' answers were identified in the first question of the questionnaire, "How do you see your child's development?" Three subcategories were established:

1. Positive beliefs: representing positive elements in interviewees' answers, relatively to three context/record units: (a) Positive beliefs in aspects related to developmental areas: the interviewees answered that they understood the development of the child as positive, emphasizing areas such as: cognitive (because of the child's intelligence), motor (because they walk) and/or linguistic (because they speak) $(n=14)$. As interviewee 0101 exemplified: "Very good, she's very smart"; (b) Positive beliefs related to developmental evolution: interviewees reported that they see the development of the child as positive, emphasizing the evolution/quality such as: being good (when presenting gains and/or progress); normal (considering the age of the child and/or other children); fast and/or healthy (as compared to other children and for overcoming difficulties, respectively) $(n=23)$. As interviewee 3601 exemplified: "Well advanced compared to her brother"; (c) Positive beliefs with aspects related to 
behaviors: interviewees reported that they understood the development of the child as positive, highlighting the good behaviors that the child presents $(n=10)$, such as: obedience, initiative, new activities, new and different behaviors, and good social interaction. As interviewee 1801 exemplified: "[...] it performs new activities, new behaviors"; (d) Positive beliefs in aspects related to the educational context: it represents a positive response of the interviewees 1201, 2101 and 2901 referring to the development of the child, emphasizing a positive influence of the day care center/ school. As interviewee 2901 exemplified: "It improved a lot after initiating school".

2. Negative Beliefs: Negative Beliefs represent negative elements in interviewees' responses, being related to the same three context and record units used for positive beliefs (with the exception of the "educational aspects" unit): (a) Negative beliefs with aspects related to developmental areas: interviewees answered that they understood the development of the child as negative emphasizing that the child has changes in the areas of language (speech) and/or motor development (walking) $(n=7)$. As exemplified by interviewee 3201: "It showed delayed, diapers, speech, walking as compared to his brother. [...]"; (b) Negative beliefs with aspects related to the evolution of development: interviewees answered that they understood the development of the child as negative emphasizing it from the evolution/quality below the expected (in comparison with the age of the child) and/or slow (compared to other children), and reported unspecified delays $(n=11)$. Exemplified by interviewees 1601 and 2001 respectively: "A little out of the ordinary" and "It is slow in comparison other children"; (c) Negative beliefs with aspects related to behaviors: the interviewees answered that they understood the development of the child as negative, emphasizing the presence of changes in the behavior of their child (a) $(n=9)$, such as when it shows disobedience, hyperactivity, problems of interaction and/or aggression. As exemplified by interviewee 2801: "Very agitated, he is hyperactive".

3. Uncertain Beliefs: The establishment of an uncertain belief occurred in the identification of dubious elements in the responses of two interviewees, in which the report did not show a "positive" and/or "negative" belief and parents" responses to this category, revealing uncertain beliefs. They are related to the following context unit/record: interviewees 1301 and 3301 responded ambiguously, reporting being "more or less good" and "too much social" respectively.

Category II entitled Contributions corresponds to the beliefs related to parental contributions to the development of the child, such as parents' actions and practices that are directed to the development of their child. Parents' answers were identified in the second question of the questionnaire: "How do you think you contribute to the development of your child?" Two subcategories were established:

(1) Positive Parental Contributions: they represent positive elements in interviewees' responses, being related to the following context/register unit: (a) Positive parental contributions: Interviewees answered that they contribute positively $(n=37)$ to child development, emphasizing aspects related to: Affectivity (attribution of love, affection, attention, zeal for the child), as in the interviewee's example 0801: "With love, affection [...]"; Moral education and behavioral issues (the interviewee recognizes being/setting an example, teaching ethics and values for good, instructing on discipline, introducing rules), which was exemplified by interviewee 0801: "[...] discipline as an example"; Stimulation (it helps the child in motor issues, cognitive and language in teaching, explaining, reading, telling stories, and following the guidelines of the specialized professionals), as in interviewee example 0601: "I stimulate it, the motor issue, the cognitive ... talking, reading to him"; Family interaction (maintains conversations, games and activities with the child, takes it to walks, dedicates and provides the child with time), which was exemplified by interviewee 1001: "We perform activities together, I participate a lot with him"; Promotion of independence (providing instructions for care, encouraging and reinforcing the child's gains), as in the example of interviewee 1801: "Understanding its gains and losses and intervening to stimulate winnings"; Providing basic needs (cares about food, hygiene, general assistance, taking the child to school and therapies, doing what he can), as exemplified by interviewee 1901: "Taking Therapies"; and Supplementary needs (seeking to do everything and/or the best for the child), as in the example of the interviewee 0401: "I try to do everything, I always try to do the best."

(2) Uncertain Parental Contributions: the establishment of an uncertain contribution occurred according to the identification of dubious elements in the interviewees' responses $(n=3)$, in which the report did not show a contribution being "positive" and/or "negative" and exposed doubts, and therefore are considered as uncertain contributions. They were related to the following context/record unit: interviewees 0201 , 0901 and 1101 responded dubiously to their contributions, reporting "The faster the child's development is the better," "With all the rush, the days are always agitated," and "He is contributing more to my development with his attitudes than the opposite," respectively.

Category III entitled Support corresponds to the persons who support the interviewee(s) in the education and care of the child. Parents' answers were identified in the third question: "Who helps you in your child's education and care?", of the questionnaire and three sub-categories were established:

(1) People in the family group: interviewees reported receiving help from family people, such as: mother (0101), father $(n=18)$, grandparents $(n=13)$, siblings $(n=6)(2801)$. As exemplified by interviewee 1601: "Brother and father".

(2) People from other groups: interviewees described that they received help from people in the educational group $(n=2)$ and the circle of friends $(n=1)$, such as teachers $(0901$ and 1001) and friends (1301). As exemplified by interviewee 0901: "Teachers".

(3) No indication of help: interviewees reported that they did not receive help from anyone $(n=11)$. As exemplified by interviewee 0201: "No one helps, the mother has to be the tough one". 
Correa, W., Minetto, M. F., Cappellaro-Kobren, R., \& Kruszielski, L. (2019). Parental Beliefs about Child Development.

The category IV Future corresponds to the beliefs related to the desires and expectations of the future for the child, that is, what these parents aspire for the future of their children. The parents' answers were identified in the fourth question "What do you want for the future of your child?", of the questionnaire and one subcategory was established:

(1) Desires of the future for the child: it represented the desires and expectations regarding the future of the child in the interviewees' answers, being related to six context/record units: (a) Desires for the future of the child with aspects related to development: the interviewees emphasized that the child progresses in certain areas of development, such as cognitive, lingistic and motor development (2001, 2201 and 2901), as exemplified by interviewee 2201: "Go, talk, run"; they also reported a desire for the child to develop within normality (0601, 1601 and 2301), as in the example of interviewee 1601: “... at least get close to normality"; they highlighted a desire for health $(0301,2101$ and 2601) for the child, emphasizing their physical well-being, as exemplified by interviewee 2601 : "Have a healthy development"; (b) Future desires for the child with aspects related to behaviors: the interviewees reported the desire for the child to present exploratory (3101) and adaptive (3201) behaviors, as exemplified in the phrases "Continue venturing, taking risks $[\ldots]$ " and "Let it be educated [...]"; (c) Future wishes for the child with aspects related to finance: interviewee 1701 described the desire for the child to have a stable financial condition: "[...] stable economic level"; (d) Future desires for the child with aspects related to academic and professional achievement: the interviewees reported their desire for the child to study, finish its studies and/or take courses at college/university $(n=17)$, as in the example of interviewee 1901: "Study hard, achieve graduation [...]"; and described the desire for the child to have a professional qualification $(n=7)$, as exemplified by the interviewee 2001: "[...] have a successful profession and be highly qualified"; (e) Future desires for the child regarding moral aspects: the interviewees reported the desire for the child to have principles and values, such as love/respect/thinking about others, be a good/honest and God-fearing person (8), as in the example of interviewee 0801: "Have principles, values, love people, live its life thinking also about other people"; (f) Future desires for the child related to independence and personal fulfillment: the interviewees described the desire for the child to be happy $(n=5)$, as in the interviewee's example 1201: "Joy, make it happy"; have independence/autonomy (0501, 0901, 1701 and 1801), as exemplified by interviewee 1801: "Autonomy, independence ..."; think about your future, go its own way and make its own choices (0901 and 1801, 3601), as in interviewee example 3601: "[...] choose what you want"; and achieve personal fulfillment, with all the best, have a future of success/brilliance, be somebody in life and develop what you need $(n=21)$, as exemplified by interviewee 2901: “[...] be somebody in life".

Category V entitled Needs corresponds to needs-related beliefs so that the child can achieve parents' future wishes, that is, what parents understand that they should meet to achieve parental expectations in their future. The answers were identified in the fifth question "What do you think is necessary for it to reach this future?" Of the questionnaire and established two subcategories

(1) Needs: it represents the needs regarding the future of the child in the interviewees' responses, being related to six contextual/record units: (a) Needs focused on development care: interviewees described that adequate development in the linguistic and motor areas (3302): “... let it walk and speak"; they also reported the need for health care (0301, 2101, 2901 and 3201) as well as good nutrition and general care, as exemplified by interviewee 2901: "[...] take care of food"; and described that it is necessary to receive specialized therapeutic care with adequate stimulation $(n=8)$, as in the example of interviewee 1801: "Being well supported by a multi-professional team ..."; (b) Financing needs: interviewee 3001 identified that a better family financial condition would be required: "You have to have money, because without money you will not be able to do anything"; (c) Needs focused on parental practices: the interviewees identified the need for the family to be affective with the child (love and affection) (0601): "We, our love, affection ..."; $(n=22)$, as exemplified by the interviewee 1501: "Parents' encouragement, we are a mirror for them"; (d) Educational needs: interviewees indicated the need for better conditions in the school environment (0201), as well as investments in technical specialization courses (0901 and 2001), the participation of children in Bible teaching (0801), and ( $n=10)$, as exemplified by the interviewee 2001: "Education at school, investments, courses"; (e) Needs related to social interactions: interviewees indicated the need for the child to have an external support network (0401 and 1601), as exemplified by interviewee 0401: "[...] more people for it to be able to count"; and the need for the child not to suffer social exclusion (1201): “[...] not feel excluded from society"; and (f) Needs focused on the child's attitudes and other ways forward: the interviewees reported the need for the child to follow its own path, such as having determination making its own choices (1101, 1901, 2301 and 3101), as exemplified by interviewee 3101: "Determination, for everything in life depends on it"; and others have stressed the importance of the child letting life and/or the world show the way (1101, 1102 and 2401), as in the example of interviewee 1102: "Life will teach."

(2) Unspecified needs: the establishment of an unspecified need occurred according to the identification of dubious elements in the interviewees' responses $(n=2)$, that is, the report did not show context/record units described above and left room for doubt, being therefore considered as unspecified needs. This was related to the following context/ record unit: interviewees 3301 and 3302 described the need for "good things", which does not fall into the pre-established categories, in addition to not specifying an objective need. As exemplified by interviewee 3301: "A lot of good things".

\section{Discussion}

The study of the parental belief system helps in the knowledge of practices of care and other forms of interaction 
between the child and his parents. The categories created (Development, Contributions, Support, Future and Needs), based on the results obtained are identified as parental beliefs, as they corroborate the literature, which describes parental beliefs as organized groups of ideas linked to actions, opinions, choices, and used as references to parental practices (Harkness \& Super, 1994, Harkness, Super, Vanna Axia, Palacios, \& Welles-Nyström, 2001).

Regarding the Development category, it was possible to identify positive and negative parental beliefs of the interviewees about the development of the children. They understand the development of these children according to certain areas and an evolution in the development, as well as the behaviors performed by them. Positive beliefs were mainly related to the actions, abilities and developmental progress of the child, as quoted by the 1801 interviewee family: "It is their gains, related to different things that they do, their progress, when they bring novelties home, carry out new activities and behaviors". As a result, research has identified that when parents identify active responses and actions (such as responding to interactions and playing with adults), this promotes greater affective attachment, generates positive feelings and adds quality to the relationship between child and caregivers (Castoldi, Gonçalves, \& Lopes, 2014; LL Nunes \& Salomão, 2016).

The negative beliefs showed that parents understand the development of their children prioritizing delays, difficulties, deficits, and/or any problems that the child presents. In this sense, the literature has shown that the arrival in the family environment of a baby in the family environment presenting some different characteristic from the idealized child (the perfect child imagined by parents) causes a structural crisis in the family, in which parents go through denial, revolt, guilt, depressive feelings and eventually experience the very mourning of the unborn child. During this process, it is common that parents overestimate the disability, attributing to it greater importance than it actually deserve (Franco, 2015, Prado, 2013).

With regard to the category Contributions, it was possible to verify in the interviewees' answers parental practices related to affectivity, moral education and behavioral issues, the concern to stimulate areas of child development, the importance of family interaction, the promotion of independence, the effort to meet basic needs and complementary needs of the child. As families 0601 and 0801 reported: "I encourage him, the motor part, cognitive ... talking, reading for him" and "With love, affection, discipline, being an example", respectively. These aspects are directly related to behaviors that these parents recognize they offer the child, thus corresponding to a relationship that is established from the conception of this child (beginning in the desire and imagination of these parents) until the child reaches adulthood (Franco, 2015). Some families recognize in this category aspects inherent in family interaction as an important contribution to the development of the child, as declared by families 1001 and 1201: "Doing activities together, participating with him" and "Participating in activities with him, playing" respectively. This is in line with Weber, Stasiak and Brandenburg (2003), who affirm that this is one of the main factors for the process of formation of the person. Thus, for professionals and researchers, the search for an understanding of the relationships between dyads in the family system (especially the relations established between parents and children) favors the organization of effective educational practices the generate quality in the development of the child (Braz, Dessen, And Silva, 2005; Weber et al., 2003).

For the Support category, interviewees report receiving help in education and caring for their children mainly from people in the family group, as indicated by people from other groups. The identified contexts are conceived as microsystems, since they point to environments in which the interaction (between dyads) is established most immediately between the person (family members, teachers or friends) and the child. The microsystem has characteristics that are directly related to the child's psychological development, such as the activities that it develops, symbolic representations and interpersonal relationships in these environments (Bronfenbrenner, 2005/2011). The maternal figure was cited only by one interviewee as the person who offers assistance in education and child care for this category (this was the one interview made with only the father). 6Mothers were present as interviewees in the other 35 families. There are several answers referring to an absence of support for the question of this category, which leads us to interpret that she (the mother) is the most present figure in the care of the child. This is corroborated by the literature, which describes that other family members participate and are involved in the daily care provided to children, but the mother is the main responsible for the education and care of children (Tudge \& Freitas, 2012 ).

Braz et al. (2005) identified the expectations of parents (belonging to the low and medium classes ) referent to their children's future, concluding that they were mainly related to the child's personality, behaviors and health. Just as the authors have pointed out answers related to interpersonal relationships, acquisition of moral values, and satisfaction in their personal choices (such as affective, scholarly and successful working lives). Similar results were identified in the present research in the Future category, where future desires for children were linked to a stable financial condition, academic and professional achievements, acquisition of principles and moral values, independence and personal fulfillment were Prado (2013) reinforces that the level of expectation of parents with regard to children with disabilities depends directly on the family socio-cultural level, that is, the higher this level, the greater the expectations regarding the development and future of the child.

Still in this category, interviewees identified their desires as related to the best development of the child, such as a better performance related to areas of their development (walking, talking), reaching normality, being healthy, developing exploratory and adaptive behaviors. These data may be related to the fact that the participating children present delays in their development. 
Correa, W., Minetto, M. F., Cappellaro-Kobren, R., \& Kruszielski, L. (2019). Parental Beliefs about Child Development.

For the Needs category, the interviewees recognized several factors as fundamental for the child to achieve the desired future, such as the importance of parental practices in this process. L.L. Nunes and Salomão (2016) and C.G. Souza, Machado, Nunes and Aquino (2014), while investigating parental beliefs about child development, described that mothers take an active role, recognize their practices in a positive way and are directed towards the care of the health, affectivity and education of the kid. The authors further emphasize that these factors were recognized by the interviewees as essential for the good development of their children, and, therefore, they sought to interact more in games with the child and worried about the safety of the child in the family environment.

Other factors were identified for this category, such as the importance of an attention to the child's development, which involved particular areas of development, primary health care and stimulation with specialized professionals, as exemplified by the interviewee family 0701: "Being stimulated to achieve the goals". The literature has pointed out that when the child's disability is understood as a challenge, it generates hope and anxiety in the family, and these aspects assume the role of motivators for parents to work in solving problems (Prado, 2013). However, parents are focused on stimulating the development and professional work directed to the specific delay presented by the, as exemplified by the 2201 interviewee family: "Continuing the treatment is what brings benefits". This is an evidence of a vision based on early stimulation. The definition of early stimulation is based on the need to stimulate impaired areas of development (such as the motor and sensory) in order for the child to obtain higher quality in them (Franco, 2015).

Better financial resources in the educational context (such as favoring conditions in this environment, investments in specializations, search for Bible teaching, and dedication by the child to studies) were also identified by parents as needs for the child to achieve the future idealized by their caregivers, as in the example of the 0901 family: "Investment in education and necessity of special attention." Social interactions to expand the network of external support and to promote social inclusion, characteristics and attitudes of the child were also pointed out by these interviewees. These elements end up corroborating the literature as being factors that interfere with and promote child development (Patias, Siqueira, \& Dias, 2013).

Overall, household responses were shown to be related to functional responses to the needs of the child (functional parents). Thus, these parents seek to accomplisheverything that is necessary (such as taking the child to school and treatment, basic care, among others), because of the responsibility and obligation to "be parents". According to Franco (2015), these parents find themselves in the elaboration of their feelings of mourning in relation to the birth of another (unwanted) child, and that their own development is blocked and needs a new stage. The author reinforces the importance of professional assistance to help the family build a new idealization of this child, an elaboration based on three main points: (1) aesthetic, to be able to identify this child as beautiful and be presented in public in a way that the others also recognize this child as being beautiful; (2) potential, that these parents may recognize that, even the child presenting some delay in its development, it is capable of performing other activities; and (3) future, that they recognize, manifesting hope, autonomy and desire, that the child has a future perspective.

Parental beliefs about child development provide strong evidence of how parents idealize their children and face the adversities of everyday family life. Thus, to obtain a parameter of these beliefs, especially when the child presents delays in its development, can favor a more effective work of family-centered programs. The fact that the families present short, uncertain answers or have doubts about what was asked by the researchers proved to be one of the elements in this research to be reviewed in future studies. As much as the researchers sought to simplify the questions, it became clear that some families had difficulty understanding what was being asked for. Regarding the method, it is advised to carry out more than one visit in the family environment and to investigate parental practices established in families of children with developmental delays. It is possible, therefore, to identify other aspects that interfere in parental beliefs, allowing a greater detail of the family system.

\section{References}

Accardo, P. J., \& Whitman, B. Y. (2003). Dictionary of developmental disabilities terminology. New York, NY: Brookes.

Ariès, P. (2014). História social da criança e da família [Child and family's social history] (D. Flaksman, Trans., 2nd ed.). Rio de Janeiro, RJ: LTC. (Original work published 1973).

Borges, L. C., \& Salomão, N. M. R. (2015). Concepções de desenvolvimento infantil e metas de socialização maternas em contexto não urbano [Concepts of child development and maternal socialization goals in nonurban context]. Estudos de Psicologia (Natal), 20(2), 114-125. doi:10.5935/1678-4669.20150013

Braz, M. P., Dessen, M. A., \& Silva, N. L. P. (2005). Relações conjugais e parentais: Uma comparação entre famílias de classes sociais baixa e média [Marital and parental relationships: A comparison of middle and working class families]. Psicologia: Reflexão e Crítica, 18(2), 151-161. doi:10.1590/S0102-79722005000200002

Bronfenbrenner, U. (2011). Bioecologia do desenvolvimento humano: Tornando os seres humanos mais humanos [Making human beings human: Bioecological perspectives on human development] (A. Carvalho-Barreto, Trans.). Porto Alegre, RS: Artmed. (Original work published 2005).

Castoldi, L., Gonçalves, T. R., \& Lopes, R. C. S. (2014). Envolvimento paterno da gestação ao primeiro ano de vida do bebê [Father involvement from pregnancy to the infant's first year of life]. Psicologia em Estudo, 19(2), 247-259. doi:10.1590/1413-737222105008 
Conciani, M. V. S., \& Rodrigues, G. S. (2014). A família socioafetiva: Uma visão crítica acerca das novas entidades familiares vinculadas ao afeto [The social affective family: A critical view about the entities new family working with the affection]. Revista Intervenção, Estado e Sociedade, 2(1), 112-127.

Ebert, M., Lorenzini, E., \& Silva, E. F. (2015). Mothers of children with autistic disorder: Perceptions and trajectories. Revista Gaúcha de Enfermagem, 36(1), 49-55. doi:10.1590/1983-1447.2015.01.43623

Franco, V. (2015). Introdução à intervenção precoce no desenvolvimento da criança: Com a família, na comunidade, em equipe [Introduction to early intervention in child development: With the family, in the community, as a team]. Évora, Portugal: Edições Aloendro.

Franco, V., \& Apolónio, A. (2010). ODIP - Organização diagnóstica em Intervenção Precoce, versão portuguesa. Évora: Universidade de Évora, 2010.

Harkness, S., \& Super, C. M. (1994). The developmental niche: A theoretical framework for analyzing the household production of health. Social Science \& Medicine, 38(2), 217-226. doi:10.1016/0277-9536(94)90391-3

Harkness, S., \& Super, C. M. (1996). Parents' cultural belief systems: Their origins, expressions, and consequences. New York, NY: Guilford.

Harkness, S., Super, C. M., Vanna Axia, A. E., Palacios, J., \& Welles-Nyström, B. (2001). Cultural pathways to successful parenting. International Society for the Study of Behavior Development Newsletter, (38), 9-11.

Nascimento, G. O. \& Fernandes, F. S. (2017). As Práticas Parentais Positivas e Negativas como fatores colaborativos no rendimento escolar [Positive and Negative Parenting Practices as collaborative factors in school performance]. Revista de Estudios e Investigación en Psicología y Educación, 5,283-288. doi:10.17979/reipe.2017.0.05.2762

Nunes, L. L., \& Salomão, N. M. (2016). O bebê aos três meses: Concepções de pais e mães [The three-month-old baby: Parents conceptions]. Psicologia em Estudo, 21(2), 245-255. doi:10.4025/psicolestud.v21i2.29197

Patias, N. D., Siqueira, A. C., \& Dias, A. C. G. (2013). Práticas educativas e intervenção com pais: A educação como proteção ao desenvolvimento dos filhos [Educative practices and intervention with parents: Education as protection to children's development]. Mudanças Psicologia da Saúde, 21(1), 29-40. doi:10.15603/21761019/mud.v21n1p29-40

Pereira-Silva, N. L., \& Dessen, M. A. (2007). Crianças com e sem síndrome de Down: Valores e crenças de pais e professores [Children with and without Down syndrome: Parental and teacher values and beliefs]. Revista Brasileira de Educação Especial, 13(3), 429-446. doi:10.1590/S1413-65382007000300009
Prado, A. F. A. (2013). Família e deficiência [Family and disability]. In C. M. O. Cerveny (Org.), Família e... Comunicação, divórcio, mudança, resiliência, deficiência, lei, bioética, doença, religião e drogadição [Family and ... Communication, divorce, change, resilience, disability, law, bioethics, disease, religion and drug addiction] (pp. 85-98). São Paulo, SP: Casa do Psicólogo.

Salvador, A. P. V., \& Weber, L. N. D. (2008). A relação entre práticas educativas e estilos parentais com o desenvolvimento de crianças e adolescentes [The relationship between educational practices and parental styles with the development of children and adolescents]. In L. N. D. Weber (Org.), Familia $e$ desenvolvimento: Visões interdisciplinares (pp. 59-79). Curitiba, PR: Juruá.

Souza, C. G., Machado, G. M. A., Nunes, L. L., \& Aquino, F. S. B. (2014). Crenças maternas sobre o desenvolvimento sociocomunicativo de bebês [Maternal beliefs about the sociocommunicative development of babies]. Temas em Psicologia, 22(2), 483-495. doi:10.9788/TP2014.2-17

Tamis-LeMonda, C. S., Adolph, K. E., Lobo, S. A., Karasik, L. B., Ishak, S., \& Dimitropoulou, K. A. (2008). When infants take mothers' advice: 18-month-olds integrate perceptual and social information to guide motor action. Developmental Psychology, 44(3), 734-746. doi:10.1037/0012-1649.44.3.734

Tudge, J. R. H., \& Freitas, L. B. L. (2012). Parentalidade: Uma abordagem ecológico-cultural [Parenting: An ecologicalcultural approach]. In C. A. Piccinini \& P. Alvarenga (Orgs.), Maternidade e paternidade: A parentalidade em diferentes contextos [Maternity and paternity: Parenting in different contexts] (pp. 171-196). São Paulo, SP: Casa do Psicólogo.

Virgilio, J. P. P., \& Gonçalves, D. A. (2013). Evolução histórica da família [Historical evolution of the family]. JICEX, 1(1), 1-13. Retrieved from http://ojs.santacruz.br/ index.php/JICEX/article/view/150/426

Weber, L., \& Dessen, M. A. (2009). Pesquisando a família: Instrumentos para coleta e análise de dados [Searching the family: Instruments for data collection and analysis]. Curitiba, PR: Juruá.

Weber, L. N. D., Stasiak, G. R., \& Brandenburg, O. J. (2003). Percepção da interação familiar e auto-estima de adolescentes [Perception of family interaction and adolescents' self-esteem]. Aletheia, (17-18), 95-105.

Yagodnik, E. B., \& Marques, G. P. Y. (2013). Princípios norteadores da reconfiguração das relações familiares na efetivação do acesso à justiça [Guiding principles of reconfiguration of family relationships in effective access to justice]. Retrieved from http://www.publicadireito. com.br/artigos/?cod=45ececbb4fa848ad 
Wesley Correa is a Master of Education of the Universidade Federal do Paraná, Curitiba-PR, Brazil.

Maria de Fátima Minetto is a Professor of the Universidade Federal do Paraná, Curitiba-PR, Brazil.

Rafaeli Cappellaro-Kobren is a Master of Education of the Universidade Federal do Paraná, Curitiba-PR, Brazil.

Leandro Kruszielski is a Professor of the Universidade Federal do Paraná, Curitiba-PR, Brazil.

Authors' Contribution:

All authors made substantial contributions to the conception and design of this study, to data analysis and interpretation, and to the manuscript revision and approval of the final version. All the authors assume public responsability for content of the manuscript.

Received: Jul. 21, 2017

1st Revision: Oct. 09, 2017

2nd Revision: Jan. 02, 2018

Approved: Mar. 092018

How to cite this article:

Correa, W., Minetto, M. F., Cappellaro-Kobren, R., \& Kruszielski, L. (2019). Crenças parentais sobre desenvolvimento infantil de crianças com atrasos no desenvolvimento. Paidéia (Ribeirão Preto), 29, e2928. doi:http://dx.doi.org/10.1590/1982-4327e2928 